\title{
Development of Groundwater Irrigation in Telangana State: Challenges, Management and Way Forward
}

\author{
Pandith Madhnure* and Lavanya, B. \\ State Ground Water Department, Government of Telangana, Hyderabad - 500 004, India \\ *E-mail: pandithmadhnure@gmail.com,
}

\begin{abstract}
Groundwater based irrigation, which was started in India as early as "Indus Civilizations" got impetus during $3^{\text {rd }}$ five-year plan. In India, at present $78 \mathrm{~m}$ ha of irrigation potential is created and 80 percent is utilized. One of the World's highest user of groundwater is India with 63 percent of its dynamic groundwater resources. Similarly, Telangana State is also utilizing the dynamic groundwater resources up to 65 percent. Groundwater a reliable source of irrigation with high yields and brings equity among its users as $\sim 99 \%$ of structures are owned by individuals. In the state, well irrigation increased from $\sim 0.46$ lakh ha from 1875 to 23.35 lakh ha during 2017-18 and well density increased to $\sim 13$ wells/ $\mathbf{k m}^{2}$ leading to decrease in irrigation potential under each well to $<1$ ha. As a result of it many challenges like water logging $\&$ salinity in canal command areas, over-exploitation leading to de-saturation of shallow aquifers, underutilization in north eastern part, groundwater pollution (both geogenic and anthropogenic) and sustainability, etc have cropped up. The management steps taken up in water sector like water transfer through KLIP, providing protected water supply through Mission Bhagiratha, de-siltation through Mission Kakatiya, forest rejuvenation through Haritha Haram, construction of various ARS, modernization of canals, conjunctive use of surface and groundwater, user centred aquifer level groundwater management, tank management, IEC activities etc brought positive changes in water availability in the state more particularly surface water. In order to sustain these efforts, formation of WUA at watershed/village level for agricultural planning, change in cropping pattern from highly intensive paddy to ID crops more particularly from non-command areas, conjunctive use of water, warabandhi (on/off) method of releasing irrigation water, developing intercepting drains, soil treatment, declaring crop holidays, separate electric grids for agriculture and domestic supply, legally separating water and land rights and strict implementation of regulatory measures. The other measures suggested are policy interventions that involve regulatory mechanisms and linking village-based institutions to government departments that manage groundwater etc.
\end{abstract}

\section{INTRODUCTION}

"Green Revolution" in early sixties led to foundation for groundwater development in India and presently it is the backbone of India's economy as $\sim 62 \%$ of irrigation, $85 \%$ drinking water needs from rural area and $50 \%$ from urban area is met through groundwater (Siebert, S. et al., 2010; Gandhi \& Bhamoriya, 2011; Ramachandra, G., 2017; Saha, D. et al., 2018 and CGWB, 2019). In India, during 1950s groundwater was developed through shallow dug wells $(<30$ feet depth), in 1970s, through dug cum bore wells (100 feet depth) and after early 80 s, through deep bore/tube wells (300-400 feet) leading to more exploitation (Singh, D., 2003 and Jeet, I., 2005). During $5^{\text {th }}$ Minor Irrigation (MI) Census, irrigation potential created was 78.9 million hectors $(\mathrm{m} \mathrm{ha})$ through groundwater \& $10.6 \mathrm{~m}$ ha through surface water schemes with $80 \%$ \& $74 \%$ utilization respectively (Govt of India, 2017). Presently at $253 \mathrm{~km}^{3} /$ year, our country is one of the highest users of groundwater in the World, utilizing 28\% of all groundwater extracted globally, ahead of the US and China (Shah, et al., 2007; Giordano, M., 2009 \& Saha and Ray, 2018). The annual per capita water availability has come down to $1381 \mathrm{~m}^{3} /$ year (as per 2018 population) from $5177 \mathrm{~m}^{3} /$ year (during 1951) and further likely reduced to $1140 \mathrm{~m}^{3} /$ year in the year 2051. Country with per capita availability of $<1700 \mathrm{~m}^{3} /$ year is said to be under water stress and thus, India is under water stress category (Sharad, J., 2019; CGWB, 2019). Among 18 major basins of India, the rivers Ganga, Godavari and Krishna holds $\sim 172,40.65$ \& 26.41 billion cubic meter $(\mathrm{bcm})$ of replenishable groundwater resources respectively (i.e., $39.6 \%, 9.4 \%$ and $6.1 \%$ of India's total resources) (Gandhi and Bhamoriya, 2011).

Though groundwater-based irrigation started during "Indus civilization" in western parts of India, but actual development started after the Famine Commission of 1880, which recommended "taccavi loans" for construction of wells. In 1883, the Govt. of India enacted the Land Improvement Loans Act, enabling it to advance money for specific land-improvement purpose (Govt. of India, 1972) and this was followed by Agriculture Loan Act, 1884 and these measures produced moderate impact on irrigation development. However, by 1900, groundwater contributed $35 \%$ to its total irritation (Govt. of India, 1972). Establishment of $1^{\text {st }}$ Irrigation Commission (1901) has given importance to development of private irrigation works, however, the Royal Commission (appointed in 1928 on agriculture) did not find significant expansion in well irrigation as irrigated areas increased very marginally from $4.68 \mathrm{~m}$ ha during $1902-03$ to $4.73 \mathrm{~m}$ ha in 1925 26 with lots of fluctuation. Decrease in flows in Ganga canal during 1931-34 gave fillip to tube well irrigation in eastern parts of Uttar Pradesh (UP), encouraged by this, Punjab started developing groundwater in Western Yamuna Canal areas and thus in 1940s, the area increased to $5.57 \mathrm{~m}$ ha. The "Grow More Food Campaign" launched during 1943 gave new stimulus in states like UP, Punjab, Bihar and Gujrat. During 1910-1950, growth in irrigation through wells was just $\sim 0.54 \%$. At the time of Independence, the share of wells in irrigation was $\sim 23 \%$ and got impetus during the $3^{\text {rd }}$ Plan, where $~ 600$ thousand wells were added. During 1988-89, Govt. of India introduced "Million Wells Schemes" (MWS) with main aim to provide free of cost open well irrigation to poor, small and marginal farmers belonging to SC/ST and freed bonded labours where 13.1 lakh wells were added with an expenditure of $\sim 4977$ crores (Mahipal, 1996; Shodhganga.inflibnet.ac.in) and this was followed by "Ganga Kalyan Yojana" (GKY) launched during 1996-97 with focus on small and marginal farmers, which couldn't give much success due to operational problems and added $\sim 7700$ beneficiaries only (Shodhganga.inflibnet.ac.in). According to Moench (2003) number of shallow \& medium wells ( $<70 \mathrm{~m}$ depth) doubled every 3.7 years 
between 1951 to 1991 and at the same time it was noticed that there was a decline in dug wells by $4.5 \%$ and increase in deep bore wells/ tube wells (> $70 \mathrm{~m}$ depth) by $80 \%$ between $4^{\text {th }}(2006-07)$ and $5^{\text {th }}$ (2013-14) MI census (Govt. of India, 2017). Studies have revealed that yields from groundwater-based irrigation are 30-50\% higher than surface water irrigation (Dhawan, 1995) and groundwater irrigation brings equity as $\sim 98.7 \%$ of structures are owned by individual farmers and rest by public (Govt. of India, 2017).

The ever-increasing demand for groundwater triggered by unplanned and uneven groundwater development leading to over exploitation in certain pockets, de-saturation of shallow aquifers, groundwater pollution and underutilization in command areas of the major projects. As per latest dynamic groundwater resource estimates (2016-2017), annual groundwater recharge is 432 billion cubic meter (bcm), annual extractable groundwater resource is $393 \mathrm{bcm}$, annual groundwater extraction for all uses is $249 \mathrm{bcm}$ of which $89 \%$ (221 $\mathrm{bcm}$ ) is used for irrigation and $27 \mathrm{bcm}$ for Domestic \& Industrial (11 $\%$ ) with average stage of groundwater extraction of $63 \%$ (CGWB, 2019). The stage of groundwater extraction is very high in the states of Delhi, Haryana, Punjab and Rajasthan, where it is $>100 \%$, in Himachal Pradesh, Tamil Nadu, Uttar Pradesh and UT's of Chandigarh and Puducherry, it is between 70-100 \%, in rest of the states/UT's, it is $<70 \%$ including Telangana where it is $\sim 65 \%$. Out of total 6881 assessment units (Blocks/Mandals/Talukas/Firkas) in the country, 1186 units $(17 \%)$ have been categorized as 'Over-Exploited'(extraction is $>100 \%$ of annual recharge), 313 units (5\%) are 'Critical', (extraction between 90-100\%), 972 as 'semi critical' units (14\%), (extraction between 70-90\%) and remaining 4310 units $(63 \%)$ as 'Safe' $(<70 \%$ extraction). Apart from these, 100 assessment units, have been categorized, as 'Saline' where groundwater in phreatic aquifers is brackish or saline in nature (CGWB, 2019).

Topography and rainfall pattern in Telangana state, made tank irrigation as an ideal type of irrigation along with knowledge and technology and till the decline and end of Kakatiya dynasty, construction of tanks was a common feature and many of the age old tanks like Ramappa, Pakhala, Laknavaram, Bayyaram etc. are still functioning. The projects like Kadam, Nizamsagar, Mir Alam, Hussain Sagar, Osmansagar, Himayatsagar, Palem, Pocharam and Ghanapuram etc are some of the important contributions by Nizam rulers (Pingale, G., 2011). The real momentum in canal irrigation came after independence when big dams like Nagarjuna Sagar, Sriram Sagar, Priyadarshini Jurala project were undertaken during various 5-year plans. The present Government has brought revolution in water sector by re-engineering of many projects like KLIP, PRLIS, Sita Rama, DLI etc.

\section{ABOUT TELANGANA STATE}

Telangana state having $\sim 1.12$ lakh $\mathrm{km}^{2}$ area lays between $15^{\circ} 50^{\prime}$ and $19^{\circ} 55^{\prime}$ north latitude and $77^{\circ} 14^{\prime}$ and $81^{\circ} 19^{\prime}$ east longitude and physiographically, broadly divided into the 'Gondwana Graben' and the 'Deccan Plateau' (GSI, 2018) (Fig.1). Geographically, the state is in a semi-arid zone having predominant hot and dry climate and drained mainly by two major rivers, the Godavari and the Krishna and their tributaries (SGWD \& CGWB, 2019). The major crops grown in the state are paddy (48\%), cotton (37\%), maize (10\%) and pulses (9\%) (DES, 2017).

\section{Rainfall (Precipitation)}

The state receives an annual rainfall from $\sim 730 \mathrm{~mm}$ (Mahabubnagar in south) to $\sim 1120 \mathrm{~mm}$ (Adilabad in north) with average rainfall of $942 \mathrm{~mm}$ in 50 days. $~ 80 \%$ of rainfall occurs during south-west monsoon months (June-September) and is the main source of recharge to groundwater, e.g., during the year 2004-05, the state received deficit rainfall $(-30 \%)$ and deep-water levels were observed
(14 m bgl) and subsequent year it received excess rainfall (+ $19 \%)$ where a rise of $2.1 \mathrm{~m}$ was observed. The rainfall data along with rainy days from 6 rain gauge station located at different rainfall zones analysed for the period 1988-89 to 2018-19. Results shows, 3 stations (Adilabad-north, Midjil-south) and Siddipet-central are showing decrease in rainy days @ 0.05, 0.16 and 0.29 days/year respectively, Sangareddy (west) and Secunderabad (Hyderabad) have shown rise in rainy days @ $0.05 \& 0.045$ days/year and Bhadrachalam (east) have shown neither rise nor fall in rainy days (Figs.2a-f). Thus, the analysis indicates that there is a negligible variation in number of rainy days even in different rainfall zones of the state.

\section{Hydrogeological Setup}

$\sim 85 \%$ of the state area is covered by hard rock aquifers namely banded gneissic complex (BGC), basalt, granite, laterite, quartzite and remaining $\sim 15 \%$ by sedimentary rocks (sandstone, limestone and shale etc) and alluvial formations (SGWD, 2019a) (Fig.1). The hard rock aquifers (BGC and granite) are essentially massive and lacks primary porosity and secondary porosity is developed due to weathering and fracturing and thus forms the productive aquifers in the state. In these rocks, weathering varies from 10-20 m depth and occasionally up to $40 \mathrm{~m}$. Studies have revealed that $\sim 95 \%$ fractures occur within $100 \mathrm{~m}$ depths having 75-150 litre/minutes (lpm) yields (CGWB, 2010; Sudarshan, et al., 2008 and Madhnure, et al., 2016). The hydraulic properties like transmissivity (T), specific yields (Sy) and storativity (S) varies from 1-630 $\mathrm{m}^{2} /$ day (with general $5-80 \mathrm{~m}^{2} /$ day), from $0.1-4$ $\%$ and from 0.00001-0.001 respectively. The boreholes drilled down to 40 to $120 \mathrm{~m}$ in basalt yielded $60-180 \mathrm{lpm}$ discharge, having transmissivity in the range of $<10-200 \mathrm{~m}^{2} /$ day and $1-2 \%$ specific yield. Gondwana rocks (soft rocks) which are deep seated (north-eastern part) forms productive aquifers between 25 and $297 \mathrm{~m}$ depth having high yields between 250 and $2000 \mathrm{lpm}$ and T between 20 and $700 \mathrm{~m}^{2} /$ day respectively. Filter point wells (5-15 m depth) are more common in river alluviums, having 150-1000 lpm of discharge.

The average annual groundwater levels (wl) during last 34 years is $9.32 \mathrm{~m}$ below ground level ( $\mathrm{m} \mathrm{bgl})$. These water levels display three distinct patterns, $1^{\text {st }}$ up to 2004-05 where shallow water levels

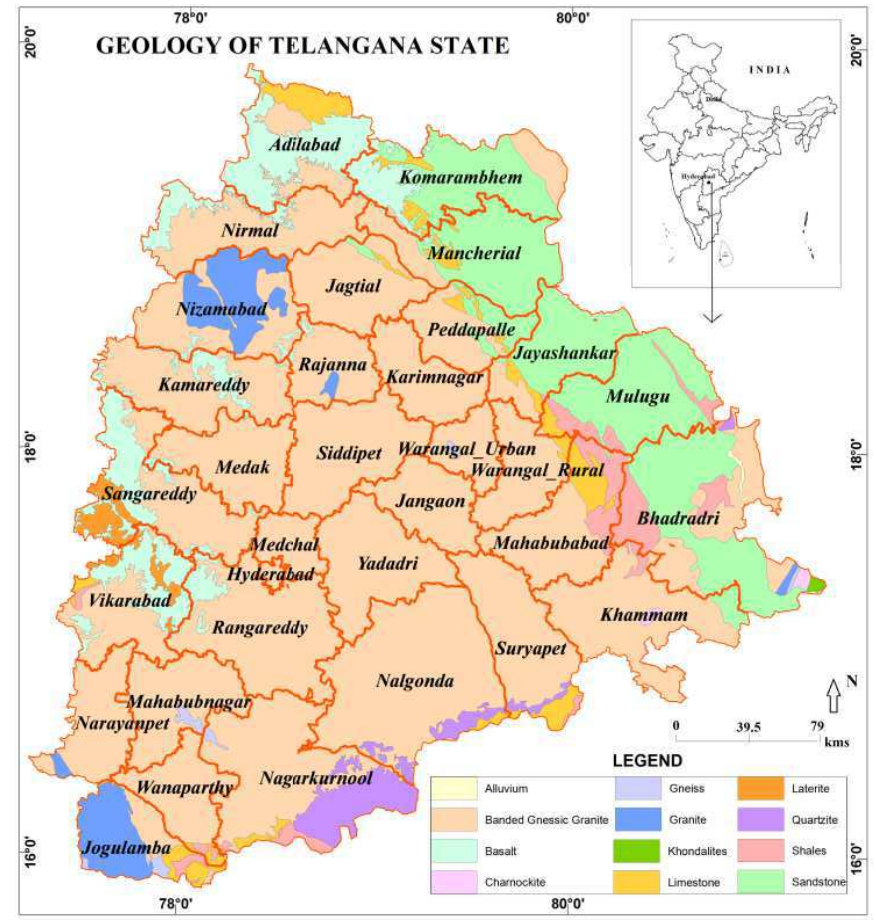

Fig.1. Geology of Telangana State. 

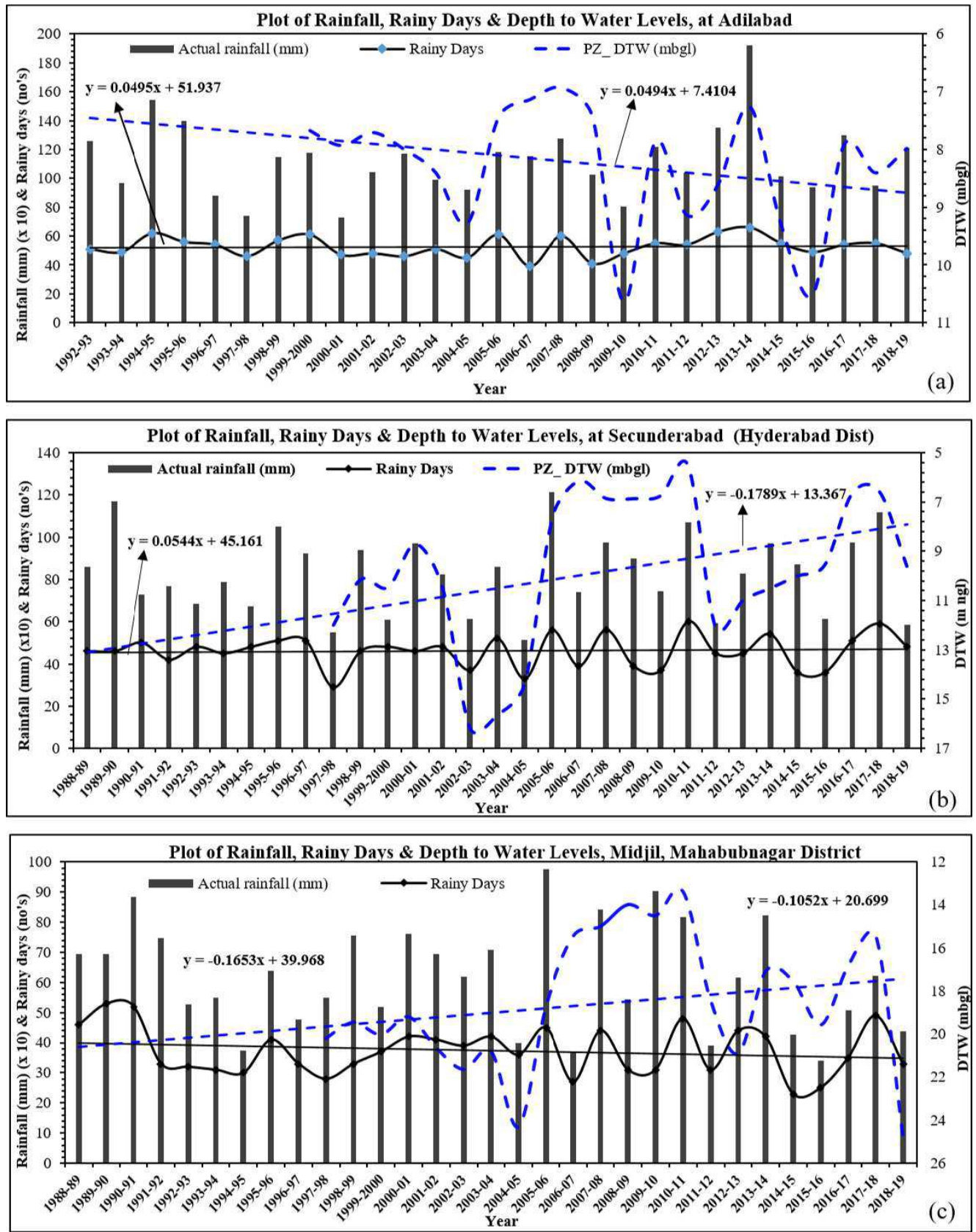

Fig.2. Plot of Rainfall, Rainy Days \& Depth to Groundwater levels located at different rainfall zones.

(average wl :8.6 m bgl) showing falling trends @ 0.4 meter/year $(\mathrm{m} /$ yr) were observed, $2^{\text {nd }}$ between 2005-06 and 2013-14 having moderate wls (average wl: $10.1 \mathrm{~m} \mathrm{bgl}$ ) and showing rising trends @ $0.08 \mathrm{~m} / \mathrm{yr}$ and $3^{\text {rd }}$ between 2014-15 \& 2018-19 (after formation of state), with deep water levels (average: $11.50 \mathrm{~m} \mathrm{bgl}$ ) and rising trends @ $0.11 \mathrm{~m} /$ yr (Figs.3a-c).

But, these water levels are not evenly distributed as observed during pre and post-monsoon season of 2019, where, shallow water levels $(<$ $10 \mathrm{~m} \mathrm{bgl}$ ) occur in northern and eastern part, deeper (> $20 \mathrm{~m} \mathrm{bgl})$ in central and western parts and moderate $(10-20 \mathrm{~m} \mathrm{bgl})$ in rest of the areas (Figure 4a-b). In order to see variations in water levels, 6 hydrograph stations having different hydrogeological setting and rainfall pattern have been studied (located at north, west, south, east and central region). Two stations viz., Adilabad in the north and Sangareddy in west are showing decline in water level trends @ 0.05 and $0.14 \mathrm{~m} /$ year respectively, 3 stations, Midjil in south and Secunderabad (Hyderabad) \& Siddipet from central part are showing rising trends@0.10,0.18\&0.35 m/year respectively and
Bhadrachalam station in east is showing neither rise nor fall in water levels. The fall in water level trends is mainly due to applied irrigation through groundwater and rise is due to increase in rainfall along with rainy days and various artificial recharge measures taken up by the state.

DYNAMIC GROUNDWATER RESOURCES (as on March 2017)

The National Water Policy of India (2012) enunciates periodic assessment of groundwater resources for quantification, sustainable development and management (Govt of India, 2012). In the state, groundwater resource estimations are carried out jointly by State Ground Water Department and Central Ground Water Board (Govt of India) and the earlier estimates carried out for the year 2002-03, 200405, 2006-07, 2008-09, 2010-11 and 2012-13 (SGWD and CGWB, 2019). The groundwater utilisation has been increasing continuously from $51 \%$ in $2006-07$ to $65 \%$ in 2016-17, whereas not much changes are observed in annual replenishable groundwater recharges (SGWD and CGWB, 2019). This is mainly due to bringing additional area 

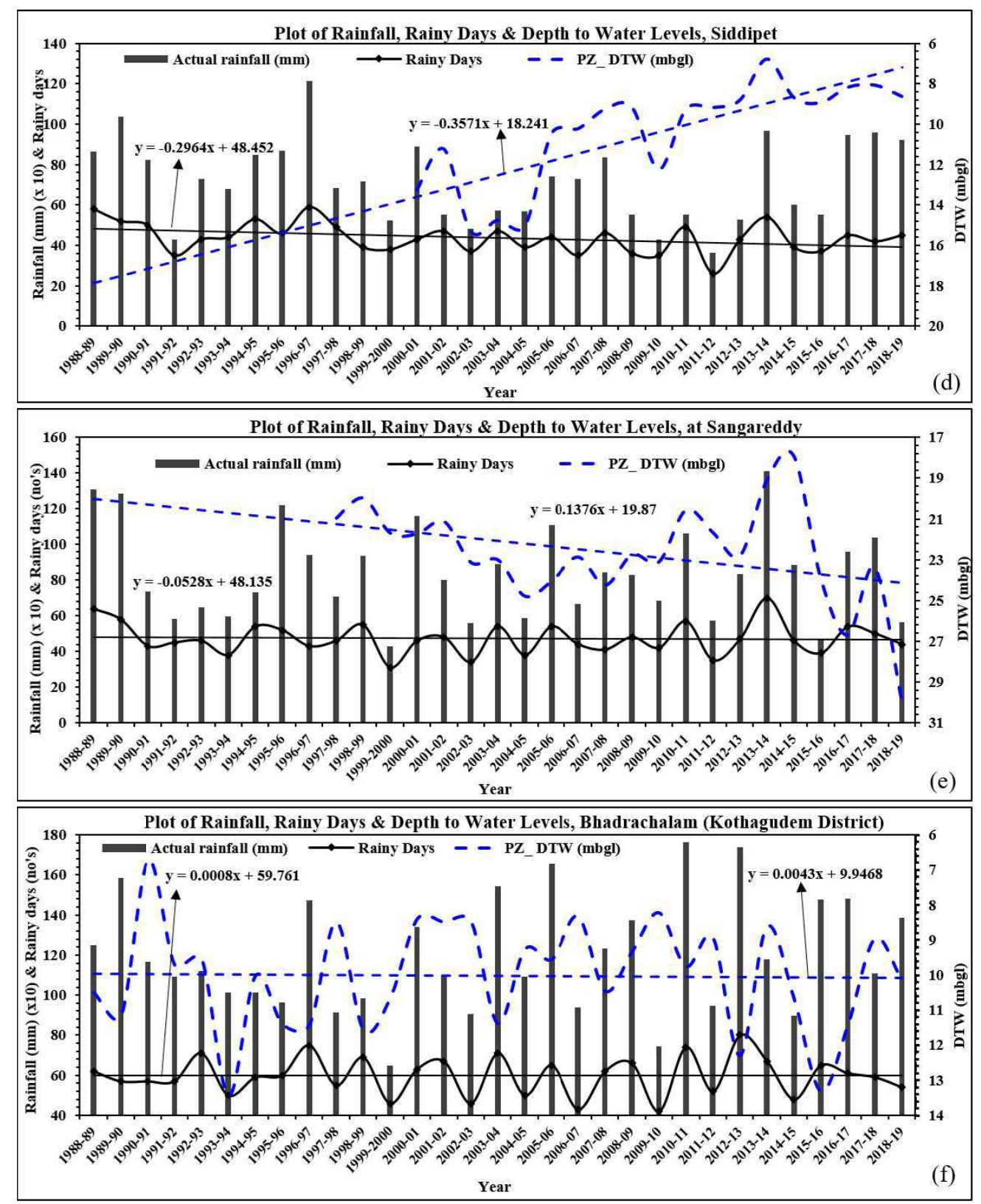

Fig.2. Contd.... Plot of Rainfall, Rainy Days \& Depth to Groundwater levels located at different rainfall zones.

under groundwater irrigation (Gross area under groundwater irrigation almost doubled from 2002-03 to 2016-17 i.e., from 12.55 lakh ha during 2002-03 to 22.43 lakh ha during 2016-17) (Table 1). The other reasons are reduction in well yields from $>150 \mathrm{~m}^{3} /$ day to $<10 \mathrm{~m}^{3} /$ day during $1 \mathrm{st}$ MI census to $>13$ wells $/ \mathrm{km}^{2}$ during $5^{\text {th }}$ MI census.

As per the latest resource estimation (2016-17), net annual groundwater availability is 12367 million cubic meter $(\mathrm{mcm})$, the current annual groundwater extraction for all uses is $8094 \mathrm{mcm}$ (7094 $\mathrm{mcm}$ for irrigation and $1001 \mathrm{mcm}$ for domestic and industrial use) and the annual extractable groundwater resource for future irrigation needs is $4325 \mathrm{mcm}$ (Table 2) (SGWD and CGWB, 2019). District wise stage of groundwater extraction varies from $23 \%$ to $94 \%$ (State average: $65 \%$ ) (Excluding Hyderabad where it is $340 \%$ ). It is noticed that out of 31 districts, 16 are categorized as high usage (> $70 \%$ usage), 7 as moderate usage (60-70\% usage) and 8 as low usage districts ( $<60 \%$ usage).

\section{STATUS OF GROUNDWATER DEVELOPMENT}

Groundwater based irrigation in the State is in existence for a long time and it was an assured source of irrigation during monsoon failure years of late $19^{\text {th }}$ century. Development of drilling technologies in hard rock areas in early 1980's, brought more area under groundwater irrigation, overtaking tank and canal irrigations (Pingale, G., 2011). Most of well irrigation in state is in the hands of individual farmers who have invested their capital in digging of dug wells, dug-cumbore wells or construction of bore/tube wells (bw/tw) fitting of pump sets and laying pipelines to their fields and the only concession given to them is free power since 2004 by earlier Govt. in 2 spells in a day (Pingale, G., 2011). From 01/01/2018, the present Govt. is giving free quality power to agriculture pump sets for 24 hours (PD, Govt. of Telangana, 2018). Presently there are $\sim 24.2$ lakh power connections to pump sets in the state (The Hindu, $20^{\text {th }}$ March 2020. COVID-19: bane for many boons for some), extracting $\sim 8084$ million cubic meter $(\mathrm{mcm})$ of groundwater for irrigation; drinking and industrial use (SGWD and CGWB, 2019).

At the time of $1^{\text {st }}$ minor irrigation (MI) census (1986-87), only 0.21 lakh bore wells/tube wells (bw/tw) were existed in the state followed by 1.23 lakh during $2^{\text {nd }}$ census (1993-94) and their numbers increased to 4.28 lakh during $3^{\text {rd }}$ census $(2000-01)$. During $5^{\text {th }}$ MI census, there are 9.51 lakh bw/tw (7 \% of country) and 5.05 lakh dug 


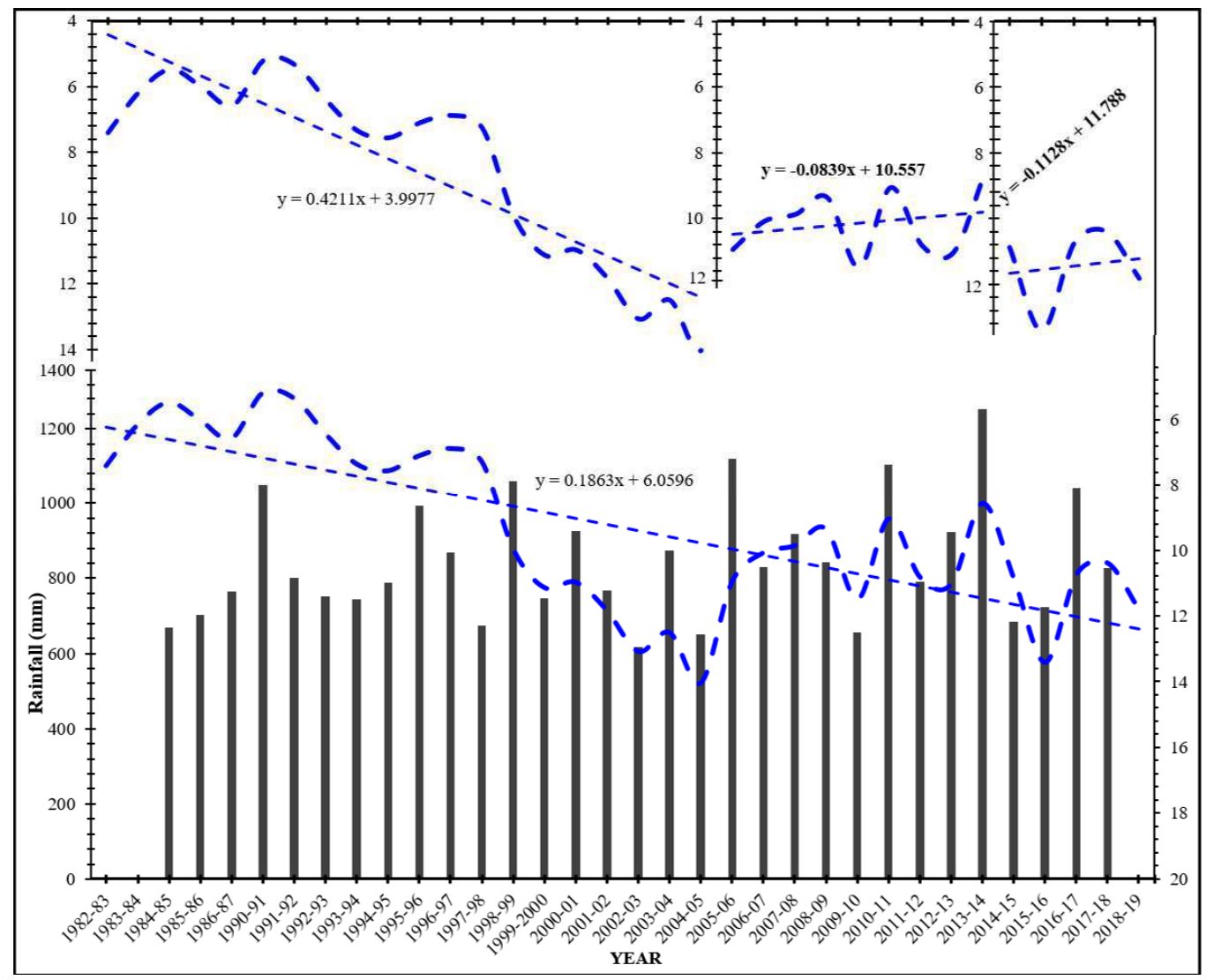

Fig.3. Average groundwater level trends and average annual rainfall $(\mathrm{mm})$ in the State.

wells (dw) in the state with a combine investment of $\sim 9120$ crores (in structures) (Govt of India, 2017). The district wise number of dug wells/bore wells/tube wells (DW/BW/TW) existing in the state during 1 to $5^{\text {th }}$ census is given in Figs.5a-b and as per $5^{\text {th }}$ MI census data, $\sim 57 \%$ of area based on groundwater is grown under kharif crops, $41 \%$ under rabi crops and $2 \%$ under perennial crops (Govt of India, 2017). In Telangana, well irrigation increased substantially from 0.46 lakh ha in 1875 (50\% to total irrigation) and reached to its maximum of 23.35 lakh ha in 2017-18 (Fig.6) (Pingale, G., 2011;
DES, 2017; NABARD, 2020). More growth was achieved after beginning of rural electrification programme under Rajiv Gandhi Grameen Vidyutikaran Yojana (RGGVY) during 2006-07 under which 26.59 lakh connections were given in the combine state of Andhra Pradesh (as on 31/10/2011) (https://pib.gov.in/newsite/PrintRelease. aspx?relid=77617). Among 3 regions of erstwhile Andhra Pradesh, in Telangana region more growth was observed (56\% of total well irrigation in combine state is contributed by Telangana farmers) (Pingale, G., 2011 and Pradeepta Kumar, S. 2015). Canal irrigation
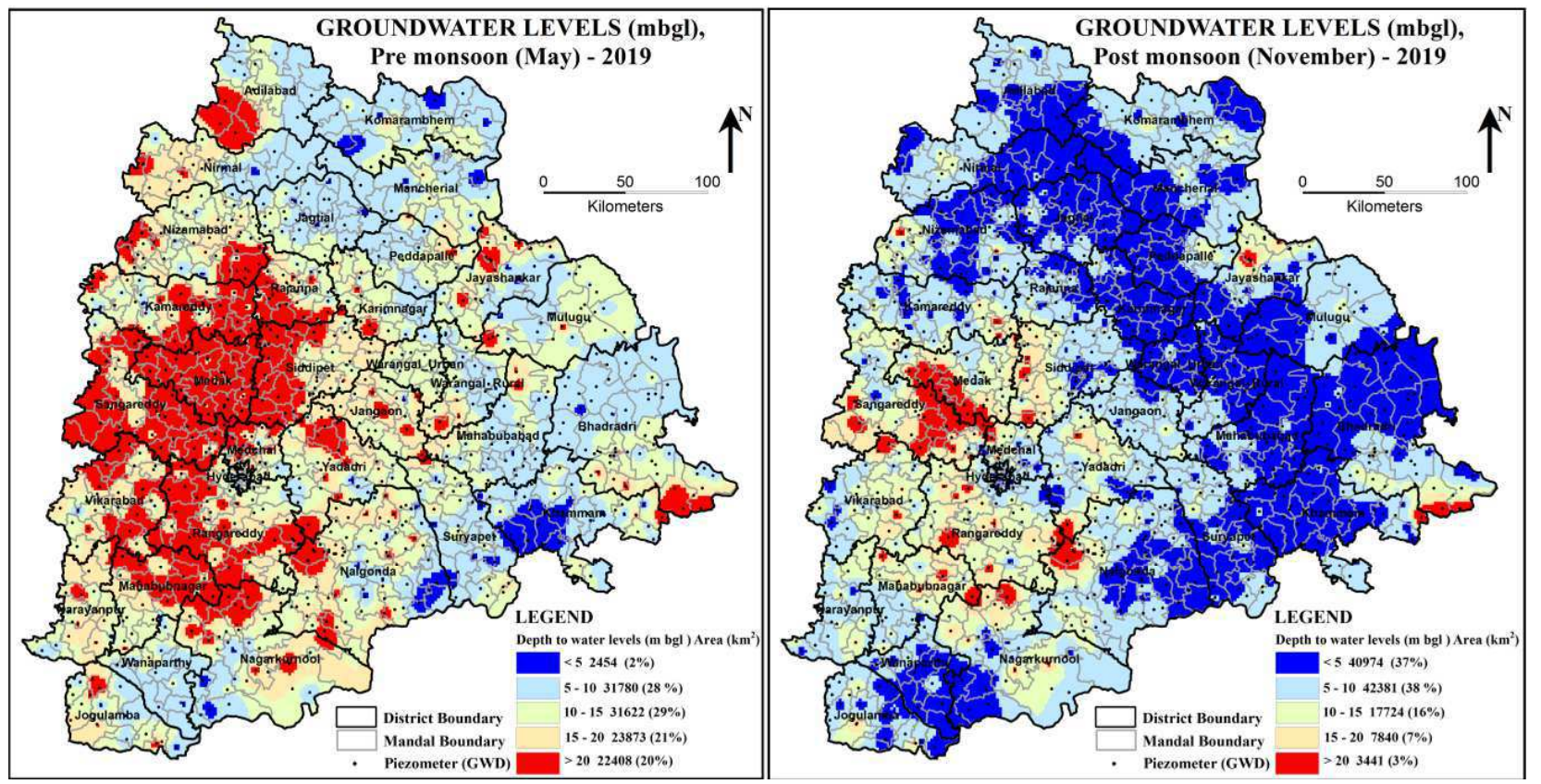

Fig.4. Areal distribution of depth to water levels (m bgl) during pre and post-monsoon season-2019. 
Table 1. Categorisation of Watersheds/Mandals during various Groundwater Estimations Years

\begin{tabular}{llccccccc}
\hline Category & Unit & $2002-03$ & $2004-05$ & $2006-07$ & $2008-09$ & $2010-11$ & $2012-13$ & $2016-17$ \\
\hline $\begin{array}{l}\text { Gross irrigated } \\
\text { area through }\end{array}$ & (lakh Ha) & 12.55 & 13.29 & 13.33 & 19.81 & 21.1 & 22.07 & 22.43 \\
$\begin{array}{l}\text { Groundwater } \\
\text { Over-exploited }\end{array}$ & Watersheds & 50 & 86 & 64 & 40 & 37 & 28 & 29 \\
(nos.) & Mandals & 98 & 102 & 74 & 38 & 42 & 46 & 70 \\
Critical & Watersheds & 29 & 37 & 27 & 16 & 8 & 29 & 59 \\
(nos.) & Mandals & 46 & 41 & 32 & 14 & 8 & 12 & 67 \\
Semi-Critical & Watersheds & 108 & 104 & 101 & 51 & 65 & 92 & 165 \\
(nos.) & Mandals & 93 & 92 & 81 & 45 & 55 & 74 & 169 \\
Safe & Watersheds & 278 & 267 & 304 & 387 & 384 & 335 & 249 \\
(nos.) & Mandals & 209 & 211 & 260 & 349 & 343 & 311 & 278 \\
\hline
\end{tabular}

reached its peak during 1990-92 and then declined and later recovered. Tank irrigation, on the other hand, declined drastically ever since 195657 when it reached its peak of 5.30 lakh ha. According to the figures of Dept. of Economic and Statistics, Govt. of Telangana (2017), the irrigation intensity is highest in Nizamabad district (1.57) and lowest in Mahabubnagar district (1.14) with average of 1.25 (Dept. of Agriculture, Govt. of Telangana, Agriculture Action Plan, 2019-24) and according to estimates the likely food grain production is 13.1 million tonnes (MT) during the year 2019-20 (PD, 2020; https:// timesofindia.indiatimes.com/city/hyderabad/ts-crop-production-in2019-20-highest-since-state-formation/articleshow/74050910.cms).
In Telangana, gradual increase in well density along with decreasing well yields (more particularly hard rocks) are observed from 5 wells $/ \mathrm{km}^{2}$ with $>150 \mathrm{~m}^{3} /$ day during $1^{\text {st }}$ MI census to $>13$ wells/ $\mathrm{km}^{2} \&<10 \mathrm{~m}^{3} /$ day during $5^{\text {th }}$ MI census respectively. It also observed that irrigation potential through each well decreased from 1-2 ha to < 1.2 ha and $\sim 11 \%$ of wells are not functioning, due to non-availability of water at shallower depths, against $20 \%$ at all India level (Govt of India, 2017). Presently, $57 \%$ of states population is dependent on some form or other on farm activity for their livelihood and agriculture contributes $\sim 9.8 \%$ to its Gross Domestic Products (GDP) (SGWD and CGWB, 2019). Studies at national level have shown, 30-50 \%

Table 2. Dynamic Groundwater Resources of Telangana, 2017 (in mcm).

\begin{tabular}{|c|c|c|c|c|c|c|c|}
\hline $\begin{array}{l}\text { S. } \\
\text { No. }\end{array}$ & District & $\begin{array}{l}\text { Net available } \\
\text { extractable } \\
\text { groundwater } \\
\text { resources }\end{array}$ & $\begin{array}{l}\text { Net } \\
\text { groundwater } \\
\text { extraction }\end{array}$ & $\begin{array}{l}\text { Allocated for } \\
\text { industrial \& } \\
\text { domestic use }\end{array}$ & $\begin{array}{c}\text { Net annual } \\
\text { groundwater } \\
\text { availability for } \\
\text { future irrigation } \\
\text { use }\end{array}$ & $\begin{array}{c}\text { Stage of } \\
\text { groundwater } \\
\text { extraction }(\%)\end{array}$ & Category \\
\hline 1 & Adilabad & 26271 & 16635 & 37.6 & 91.5 & 63 & Safe \\
\hline 2 & Bhadradri_Kothagudem & 74058 & 19934 & 43.3 & 534.1 & 27 & Safe \\
\hline 3 & Hyderabad & 4148 & 14164 & 0.0 & 0.0 & 341 & $\mathrm{OE}$ \\
\hline 4 & Jagityal & 42374 & 31224 & 55.3 & 134.3 & 74 & $\mathrm{SC}$ \\
\hline 5 & Jangaon & 30095 & 27793 & 20.5 & 25.9 & 92 & Critical \\
\hline 6 & Jayashankar Bupalapally & 27835 & 17698 & 15.9 & 101.4 & 64 & safe \\
\hline 7 & Jogulamba_Gadwal & 18787 & 8669 & 12.0 & 94.4 & 46 & Safe \\
\hline 8 & Kamareddy & 46636 & 35993 & 39.1 & 90.3 & 77 & $\mathrm{SC}$ \\
\hline 9 & Karimnagar & 33161 & 24965 & 36.7 & 71.7 & 75 & $\mathrm{SC}$ \\
\hline 10 & Khammam & 58886 & 38115 & 50.2 & 222.9 & 65 & Safe \\
\hline 11 & Komurambheem_Asifabad & 32352 & 7337 & 21.5 & 248.8 & 23 & Safe \\
\hline 12 & Mahabubabad & 40081 & 28886 & 33.9 & 111.5 & 72 & $\mathrm{SC}$ \\
\hline 13 & Mahabubnagar & 27464 & 20349 & 24.6 & 71.2 & 74 & $\mathrm{SC}$ \\
\hline 14 & Mancherial & 53581 & 21982 & 25.6 & 306.7 & 41 & Safe \\
\hline 15 & Medak & 38571 & 24608 & 27.9 & 120.9 & 64 & Safe \\
\hline 16 & Medchal_Malkajgiri & 7753 & 7286 & 49.7 & 8.8 & 94 & Critical \\
\hline 17 & Mulugu & 31197 & 13323 & 10.9 & 178.7 & 43 & Safe \\
\hline 18 & Nagarkurnool & 48291 & 31825 & 47.4 & 161.4 & 66 & Safe \\
\hline 19 & Nalgonda & 75324 & 55920 & 76.4 & 203.4 & 74 & $\mathrm{SC}$ \\
\hline 20 & Narayanpet & 19843 & 11968 & 16.6 & 78.8 & 60 & Safe \\
\hline 21 & Nirmal & 50469 & 18718 & 22.7 & 315.2 & 37 & Safe \\
\hline 22 & Nizamabad & 74891 & 56496 & 55.5 & 189.8 & 75 & $\mathrm{SC}$ \\
\hline 23 & Peddapalli & 39949 & 20864 & 28.6 & 180.4 & 52 & Safe \\
\hline 24 & Rajanna_Sircilla & 24324 & 19998 & 18.8 & 45.8 & 82 & $\mathrm{SC}$ \\
\hline 25 & Rangareddy & 37988 & 30881 & 61.8 & 68.9 & 81 & $\mathrm{SC}$ \\
\hline 26 & Sangareddy & 38071 & 26876 & 59.5 & 101.0 & 71 & $\mathrm{SC}$ \\
\hline 27 & Siddipet & 46510 & 43608 & 44.2 & 34.4 & 94 & Critical \\
\hline 28 & Suryapet & 49896 & 30569 & 43.4 & 177.9 & 61 & Safe \\
\hline 29 & Vikarabad & 33069 & 18624 & 36.5 & 137.9 & 56 & Safe \\
\hline 30 & Wanaparthy & 17200 & 11536 & 19.8 & 52.6 & 67 & Safe \\
\hline 31 & Warangal_Rural & 32018 & 27584 & 27.6 & 51.9 & 86 & $\mathrm{SC}$ \\
\hline 32 & Warangal_Urban & 20167 & 18340 & 22.8 & 31.9 & 91 & Critical \\
\hline \multirow[t]{2}{*}{33} & Yadadri_Bhuvanagiri & 35450 & 26579 & 37.1 & 80.0 & 75 & $\mathrm{SC}$ \\
\hline & & 12367 & 8093 & 1123 & 4325 & 65 & \\
\hline
\end{tabular}

(Note: SC-Semi-critical). 

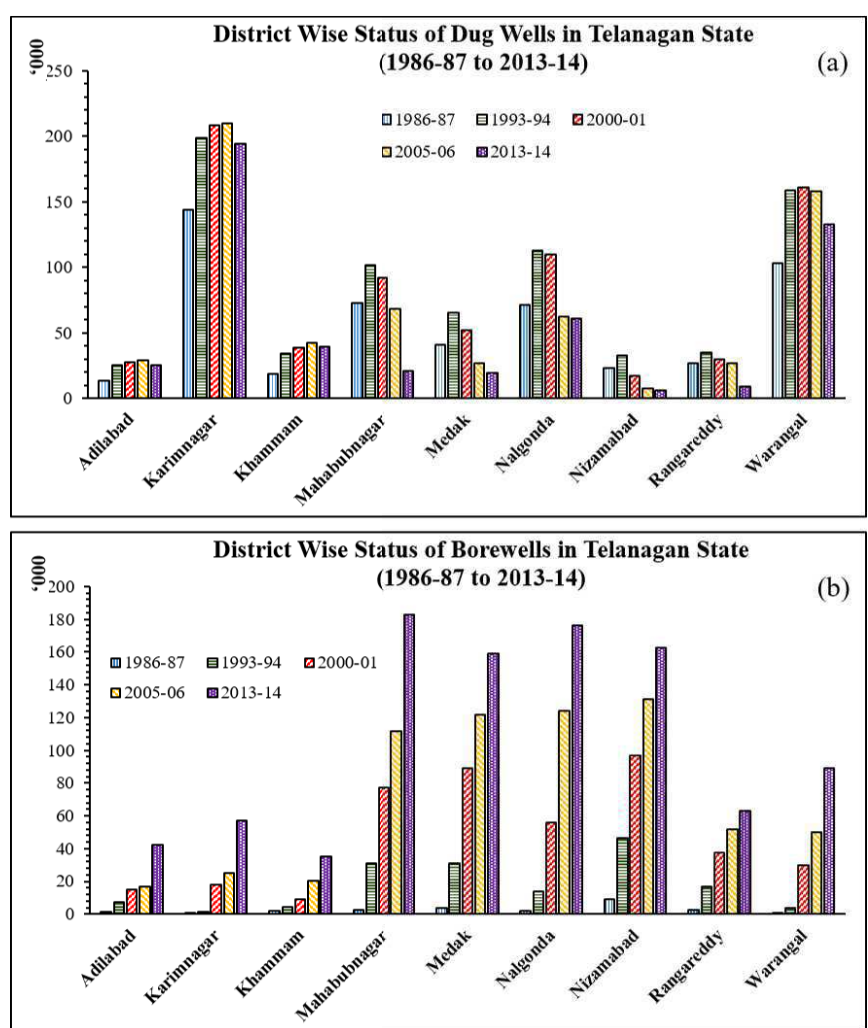

Fig.5. District wise status of dug wells/bore wells, in Telangana State (1986-87 to 2013-14).

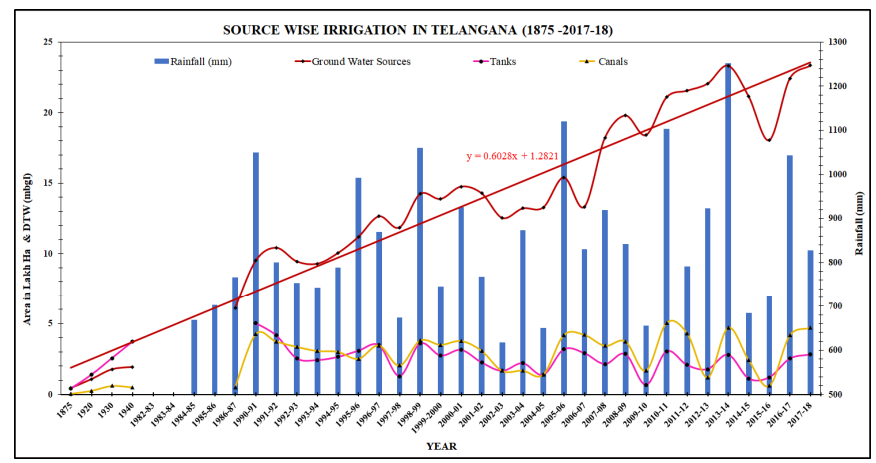

Fig.6. Source wise irrigation in Telangana State.

higher crop yields through groundwater (from well owned by farmer) compared to canal irrigation because it delivered precisely when required and its judicious use by farmers (Shah, et al., 2000; Dhawan, 1995; FAO, 2011, Foster, et al., 2015).

After the formation of Telangana State, the present Government has brought revolution in water sector like re-engineering of Pranahita Chevella Sujala Shravanthi Projects (PCSSP) into Dr. B.R. Ambedkar Pranahita Project and Kaleshwaram Lift Irrigation Project (KLIP). Sitarama Project, Palamuru-Rangareddy Lift Irrigation Scheme (PRLIS), Bhakta Ramdasu Project (BRP), Dindi lift irrigation (DLI) etc. The completed, under completion and contemplated irrigation projects (major and medium) in the state are depicted in Fig.7. Besides, rejuvenation of minor irrigation tanks under Mission Kakatiya, Mission Bhagiratha Project is implemented to ensure safe and sustainable piped drinking water supply, Haritha Haram Project to rejuvenate the degraded forest cover, soil conservation \& moisture retention, construction of 1200 check dams on $4^{\text {th }}$ order and above streams, construction of $>200$ recharge shafts in existing water bodies in over-exploited watersheds etc are also taken up by the Government of Telangana.

\section{CHALLENGES AND ITS MANAGEMENT}

In the state, groundwater resources are not extracted evenly, and it is mainly concentrated in central part. There are areas in the north-eastern part of the state where additional development of groundwater resources is possible (SGWD \& CGWB, 2019). This unplanned and uneven development of groundwater is leading to many challenges like water logging (over abundance) and salinity in few pockets, over-exploitation leading to de-saturation of shallow aquifers in central and western part of state, groundwater pollution due to fluoride (geogenic) and anthropogenic due to nitrate and sustainability etc.

Water Logging (over abundance): Water logging is caused due to saturation of soil pores by water in crop root zones and this is mainly due to rise in sub-soil water table (Govt. of India, 1972 and CGWB, 2019). Other causes are periodic flooding, overflow by runoff, over irrigation, artesian conditions and impeded sub-surface drainage. These conditions affect growth and yield of crops and in course of time such lands become saline and alkaline and ultimately become unfit for cultivation. In the State water logging conditions are mainly observed mainly in canal command areas of Nagarjuna Sagar Left Bank Canal (NSLC), Sri Ram Sagar Project (SRSP) canal command and Rajoli Banda canal command area of Ieeza and Alampur mandal of Jogulamba Gadwal District. During post-monsoon season of 2019, out of 5242 $\mathrm{km}^{2}$ area from NSLC and $9343 \mathrm{~km}^{2}$ from SRSP, water logging $(<2 \mathrm{~m}$ bgl) and prone to water logging conditions (2-3 m bgl) are observed in $\sim 1163 \mathrm{~km}^{2}(22 \%)$ and $2682 \mathrm{~km}^{2}(28 \%)$ area respectively, whereas, during May-2019 (pre-monsoon season) $19 \%$ and $<1 \%$ area was occupied. Based on 10 years average water level data (2010-19), it is observed that permanent logging and prone to water logging conditions affecting crop growth and yields are observed in $2 \%$ and $52 \%$ of command area of NSLC during post monsoon season. Whereas, in SRSP and Rajoli Bandha command area only prone to water logging conditions are observed in $7 \%$ and $8 \%$ of command area respectively. Whereas, during pre-monsoon season prone to water logging conditions are observed in $2 \%$ of NSLC command area only.

Salinity: The inland or secondary salinity (EC > $3000 \mu \mathrm{Siem} / \mathrm{cm}$ at $25{ }^{\circ} \mathrm{C}$ ) is observed in $1 \%$ of State area during both pre-as well as post-monsoon seasons of 2019 mostly in parts of Rajoli Banda (Jogulamba Gadwal District) and NSLC area from Nalgonda, Suryapet $\&$ Khammam and eastern parts from Yadadri districts. Prone for salinity (where EC between 2250-3000 $\mu \mathrm{Siem} / \mathrm{cm}$ at $25^{\circ} \mathrm{C}$ ) occupies $3 \%$ and $5 \%$ of area during pre-\& post monsoon seasons of the same period (SGWB, 2019b).

Over utilization: In the state $\sim 16 \%$ villages (1745 nos.), 29 watersheds (out of 502 watersheds) and 70 mandals (out of 589) and entire Hyderabad district falls under "over-exploited" category (extraction is $>100 \%$ to its annual recharge in the dynamic zone) mainly covering central and western part of state (SGWD \& CGWB, 2019) (Figs.8a-b). The over-exploitation of groundwater resources is leading to decline in groundwater levels in the state from 1982-83 to 2018-19 (@ 0.18 m/year) (Figs.3a-c). In the last decade (2010-19). $\sim 10 \%$ of wells both during pre and post-monsoon season are showing fall in water levels during 2019 as compared to average of last 10 years, more particularly in central and western part of state and this is leading to de-saturation of shallow aquifer (wls more than $20 \mathrm{~m} \mathrm{bgl}$ ) in $\sim 6 \%$ and $\sim 1 \%$ of state area during pre and post-monsoon season respectively (more particularly in central part of Medak, southern part of Siddipet and Rangareddy and northern part of Nagarkurnool districts).

Under Utilization: Out of 31 districts (now 33 districts), low 


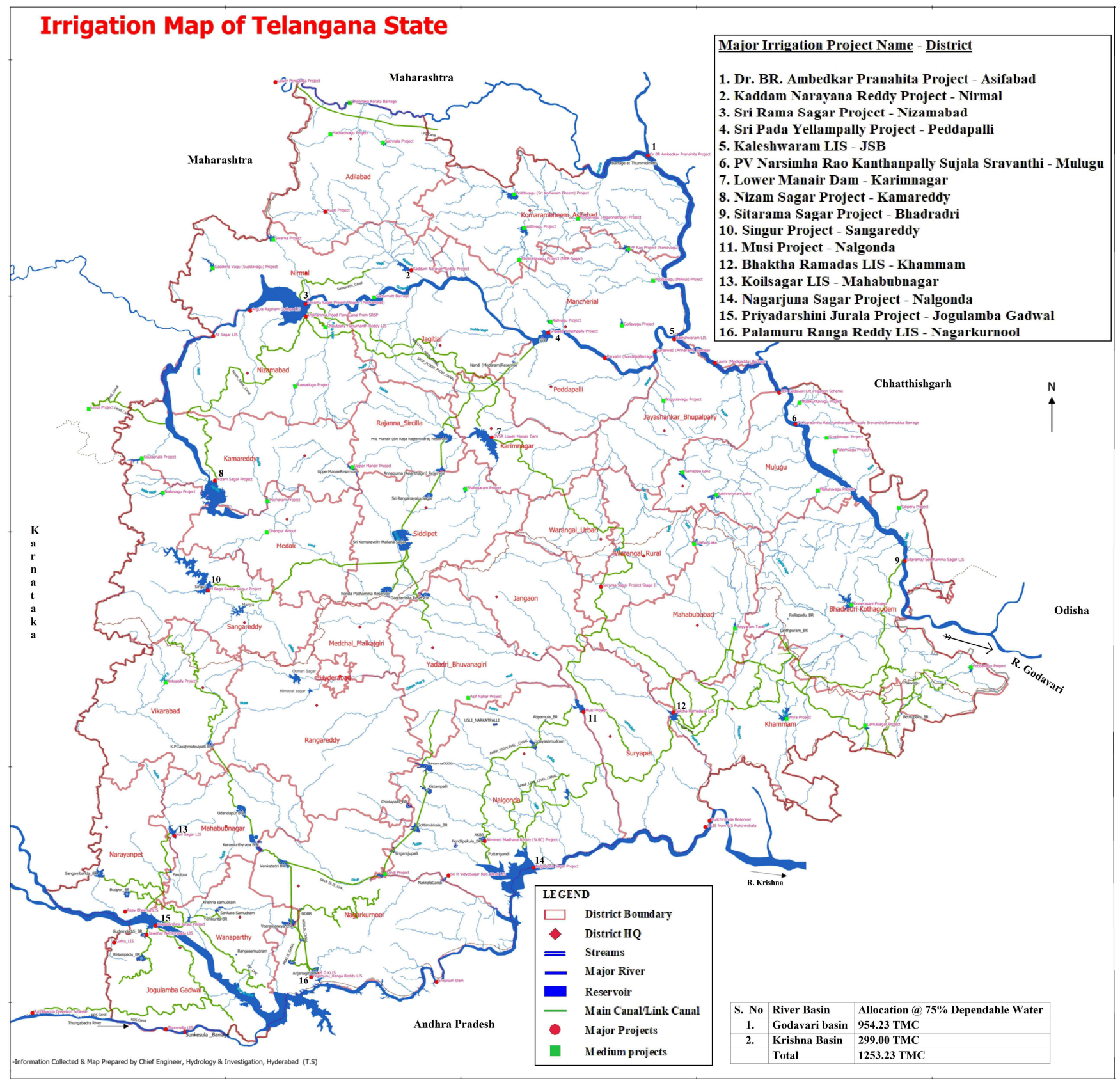

Fig.7. Irrigation map of Telangana State.

utilization of groundwater resources (23-60\% usage) is observed in 8 districts covering north-eastern part of state. These districts are underlain by highly potential Gondwana sandstone aquifer where resources can be further developed to alleviate the poverty and to bring prosperity \& socio-economic equity among the rural population.

Groundwater quality deterioration: Groundwater quality in some areas is deteriorated due to geogenic contamination by fluoride $(\mathrm{F})$. Fluoride concentration beyond maximum drinking permissible limits of $1.5 \mathrm{mg} / \mathrm{l}$ (BIS, 2012) is observed in $15 \%$ \& $11 \%$ of state area during pre- $\&$ post monsoon seasons of 2019 respectively (Figs.9a-b). High concentration of $\mathrm{F}^{-}(>1.5 \mathrm{mg} / \mathrm{l})$ in localized patches are detected in Nalgonda, Kamareddy, Warangal (U), Sangareddy, Rangareddy, Jagityal, Yadadri-Bhongir and Asifabad districts in both seasons. Uranium $(U)$ is other geogenic contamination which occurs in southern parts of Nalgonda and north-eastern parts of Nagarkurnool district where, its concentration is $>60 \mathrm{ppb}$ (exceeding maximum drinking water standards $(60 \mathrm{ppb})$ prescribed by Atomic Energy Regulatory Board, 2004). The other causes of deterioration in groundwater quality is occurrence of $\mathrm{NO}_{3}$ an anthropogenic contaminant due to excess utilization of fertilizers and nitrogen fixation by leguminous plant in canal command area of Rajoli Banda, NSLC \& SRSP and major urban centres. During pre-\& post-monsoon seasons of 2019, 46\% samples (out of 8700 samples) falls above maximum permissible limits of 45 $\mathrm{mg} / \mathrm{l}$ (BIS, 2012). The other anthropogenic contaminations are due to occurrence of heavy metals such as $\mathrm{Fe}, \mathrm{Cd}, \mathrm{Mn} \& \mathrm{Ni}$ in Katedan; Fe, $\mathrm{Zn}, \mathrm{Cd}, \mathrm{Pb}$ and $\mathrm{Cr}$ in Jeedimetla-Balanagar; $\mathrm{Ni}, \mathrm{Cd}, \mathrm{Fe}$ and $\mathrm{Mn}$ in Nacharam and $\mathrm{Pb}, \mathrm{Ni}, \mathrm{Mn}, \mathrm{Cd}$ and $\mathrm{Cr}$ in Jinnaram industrial areas of the state (Sudarshan, et al.,2008 and SGWD, 2019b).

Sustainability: Gradual increase in well density from 5 wells $/ \mathrm{km}^{2}$ during 1 st MI census to $>13$ wells $/ \mathrm{km}^{2}$ during $5^{\text {th }}$ MI census has resulted in decreasing well yields from $>150 \mathrm{~m}^{3} /$ day to $<10 \mathrm{~m}^{3} /$ day and due to this irrigation potential under each well reduced from 1-2 ha to $<1.2$ ha (Sudarshan et al., 2008 and Govt of India, 2017). This phenomenon is more common in central \& southern part of State (underlain by compact hard rocks) where comparatively more bore wells are there than dug wells. 


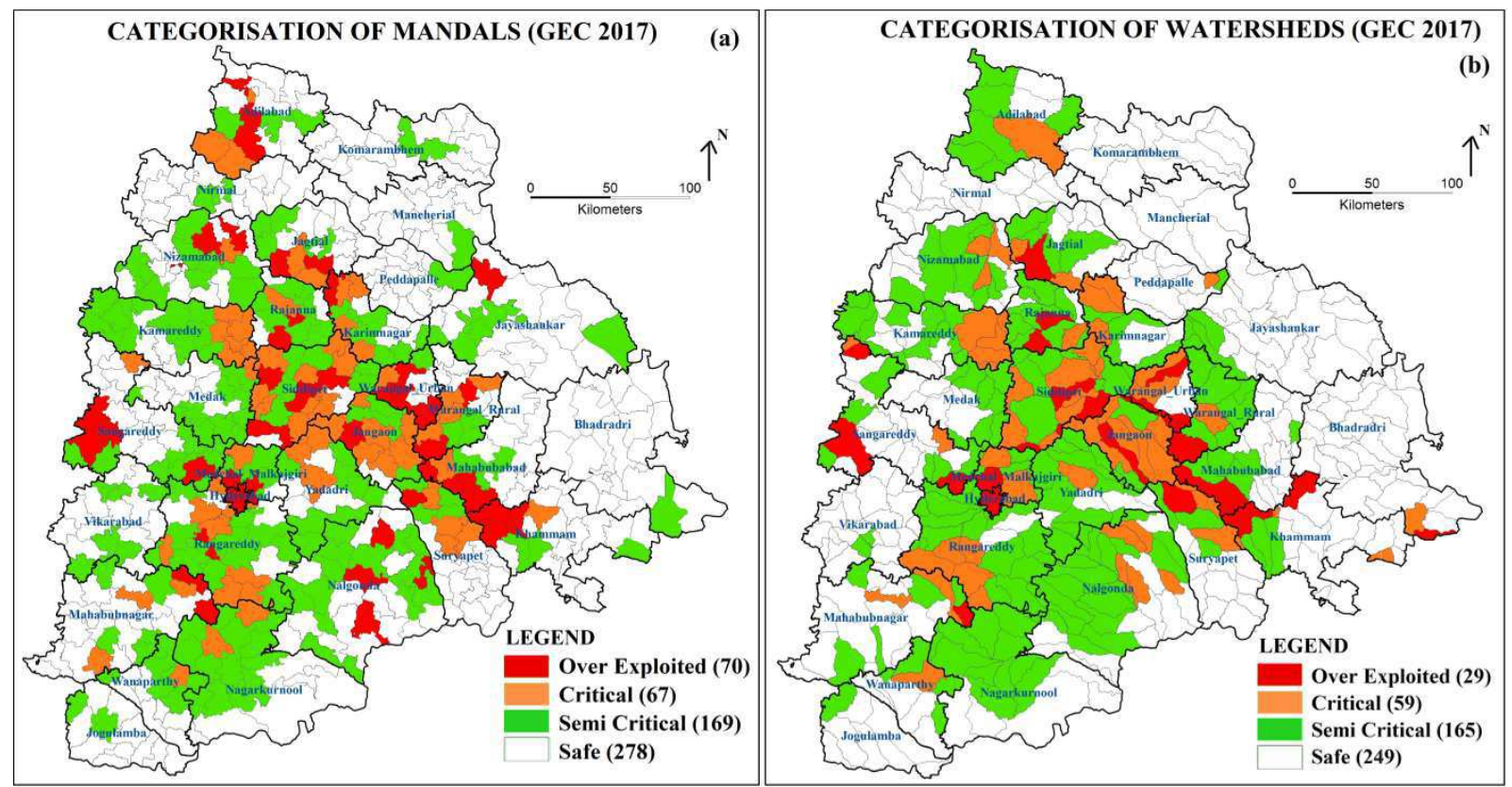

Fig.8. Categorisation of Mandals and Wtaersheds (GEC-2017).

\section{Management Strategies}

To overcome above issues, the Government of Telangana has taken up a giant step in managing water resources (both surface and groundwater) by adopting technological and institutional solutions.

The major technological solution adopted by State is re-engineering of Pranahita Chevella Sujala Shravanthi projects (PCSSP) into Dr. B.R. Ambedkar Pranahita project \& Kaleshwaram Lift Irrigation project (KLIP). Dr. B.R. Ambedkar Pranahita project is constructed across river Pranahita at Tummidi Hetti (Asifabad district) for diversion of 20 thousand million cubic feet (TMC) of water to irrigate $\sim 2$ lakh acres in Asifabad and Mancherial districts. The KLIP, one of the biggest lift irrigation project in the World is constructed on the river Godavari at Medigadda at 90 meter above mean sea level ( $\mathrm{m}$ amsl) and to lift $\sim 180$ TMC water in stages to $>600 \mathrm{~m}$ amsl height into the mainland canals to irrigate additional 18.25 lakh acres area in 13 districts. It will also cater to the drinking water needs of Greater Hyderabad Municipal Corporation (GHMC) area up to outer ring road and enroute villages. The releasing of water into mainland canals during 2019 "Yasangi" (rabi) season has shown positive impact on water levels as shallow water level area $(<10 \mathrm{~m} \mathrm{bgl})$ which, occupied $27 \%$ of total command area during post-monsoon season (November) of last decade (2009-18) increased to $51 \%$ during the same season of 2019 (Source: SGWD data base). The other major schemes taken up to irrigate are the Sitarama project, to irrigate $\sim 3.29$ lakh acres in Khammam district; the Palamuru-Rangareddy Lift irrigation Scheme to irrigate $~ 12.5$ lakh acres in Rangareddy and Mahabubnagar districts; the Bhakta Ramdasu project to irrigate $~ 0.6$ lakh acres in Khammam district; the Dindi lift irrigation project in Nagarkurnool and Nalgonda district to irrigate $\sim 3.4$ lakh acres and to mitigate drinking water needs of fluorosis endemic villages.

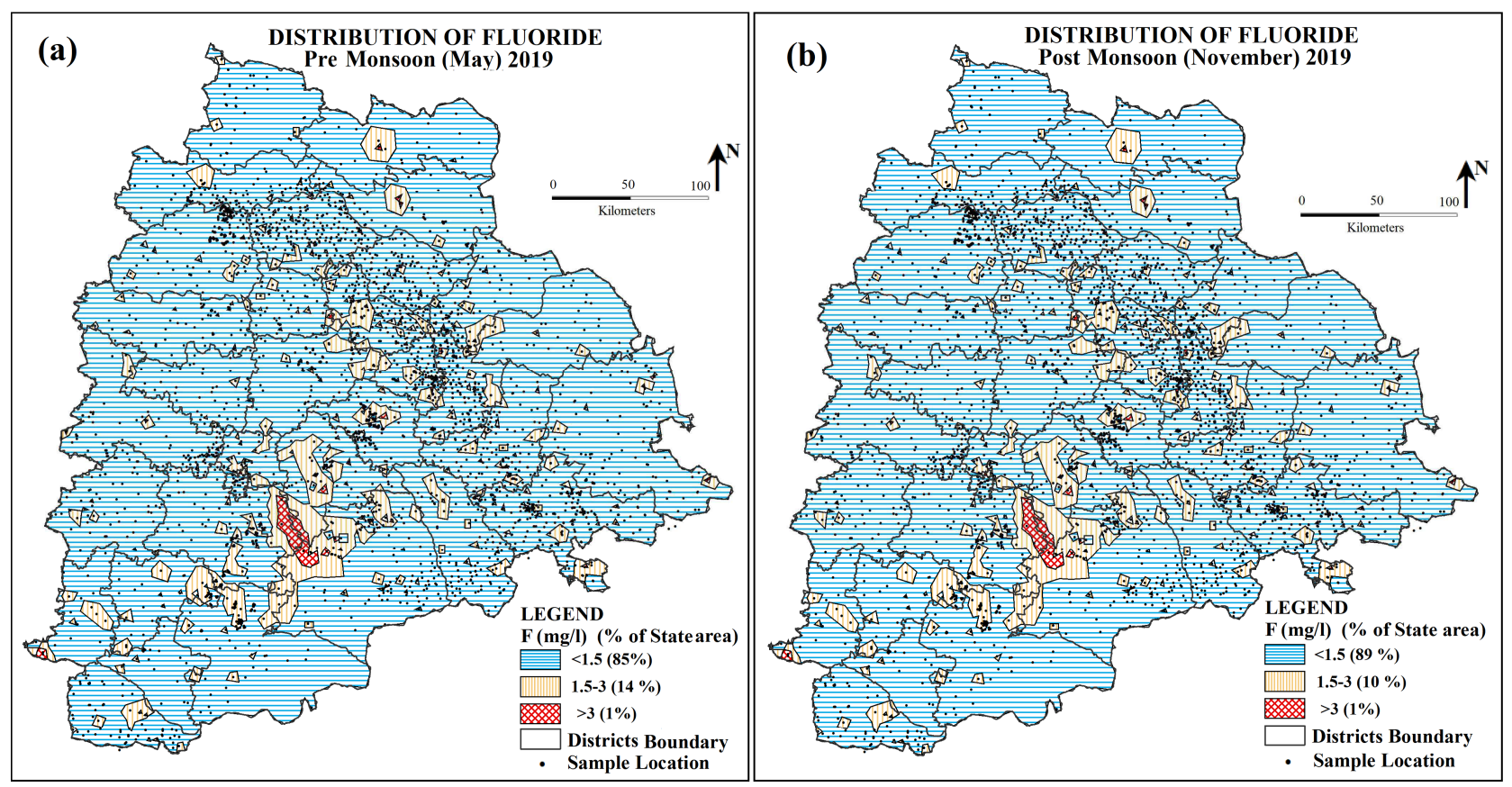

Fig.9. Distribution of fluoride during pre and post-monsoon season-2019. 
The other measures include Mission Kakatiya, to fill up the gap ayacut of $\sim 10$ lakh acres, by restoration of existing $\sim 46530$ MI tanks in phased manner and by end of March 2018 (till $4^{\text {th }}$ phase) 27700 tanks are taken up which, has created a perceptible impact on agriculture and their livelihood, benefitting small and marginal farmers (NABCONS). To ensure safe and sustainable piped drinking water supply from surface water sources Mission Bhagiratha project is taken up at a cost of $\sim 42853$ crores to provide @ 100/135 and 150 litres/ capita/day (lpcd) of water in rural, urban and municipal areas and for industrial supply by bringing $~ 86$ TMC of surface water and this imported water (surface) from outside the basins (watersheds) will definitely save the groundwater resources in the basins/watersheds. To rejuvenate the degraded forest cover from $24 \%$ to $33 \%$ and for soil and moisture conservation on watershed approach, Haritha Haram project was started in July 2015 and so far, (up to 2019), $\sim 81.6$ crores seedlings are planted. To bring on fast track of Accelerated Irrigation Benefit Program (AIBP) under Long Term Irrigation Funds (LTIF), Govt under PMKSY sanctioned an amount of Rs.3413 crores and released Rs.297 crores to complete existing projects at early date (https://www.nabard.org/content 1 .aspx id=655\&catid= $8 \&$ mid $=488$ ).

As recharge measures, the Govt has constructed $>19000$ various artificial recharge structures (ARS) in the state and recently sanctioned construction of an additional of 1200 new check dams (CD) on the $4^{\text {th }}$ and above order streams with NABARD funding and work is already grounded for $600 \mathrm{CD}$ 's this year. To recharge the de-saturated aquifers in over-exploited villages, the SGWD has taken up construction of recharge shafts in existing water bodies (202 no's) and already completed 138 structures including the Chief Minister adopted 2 villages in Medchal-Malkajgiri district. According to NABARD, there is a need as well as good scope for bank financing of new irrigation, recharge structures, pumping systems etc and for considering it, the credit potential of Rs $935.18 \mathrm{Cr}$ is assessed for water sector in the state for the year 2020-21 (NABARD, 2020).

The demand side measures like Andhra Pradesh Farmer Managed Groundwater System (APFAMGS) with FAO funding and Andhra Pradesh and Telangana State Community Based Tank Management Programme (AP \& TS CBTMP with World Bank funding was adopted in erstwhile Andhra Pradesh state (including erstwhile Nalgonda and Medak districts from present Telangana state) (World Bank, 2019). Review of results from APFAMGS implemented areas shows improved awareness and behavioural changes, this helped the communities to adapt to droughts because of a shift from monocrop culture to mixed/ multiple crops (Reddy, V.R. and Reddy, M.S., 2020). World Bank funded restructuring and modernization of canals of NSLC area, User centred aquifer level groundwater management pilot study in Nalgonda district and conjunctive use of surface and groundwater in NSLC from Khammam district under water sector improvement project (WSIP) were taken up. The aquifer level groundwater management plan from Nalgonda district was taken up to develop institutional model and community based water management plan for which the SGWD, Govt of Telangana received Rs. 1 lakh cash prize $\left(3^{\text {rd }}\right.$ position) from $1^{\text {st }}$ National Water Mission, MOWR, Govt of India during 2019. The other measures include water conservation measures under MGNREG, on and off method of releasing of canal water in NSLC command area and by adopting water saving technological solutions. The state has brought $\sim 7.42$ lakh ha area under micro irrigation from $\sim 95000$ ha benefitting 7.46 lakh farmers during 2016 under Micro Irrigation Project (MIP) (Suresh and Manoj, 2020) (http://horticulture.tg.nic.in/ TSMIP/TSMIP.html). The other water saving measures includes changing cropping pattern to low water consuming crops like oil seeds, palm oil cultivation, ground nut, pulses etc., enhancing support price for dry crops, implementation of Jalam-Jeevam a rainwater harvesting programme in GHMC area etc. To bring awareness among the farmers/ students and users for conserving water, awareness is created under Jal Shakti Abhiyan and under National Hydrology Project (NHP) in 139 over-exploited and critical mandals. The department is creating information, education and communication (IEC) activities in overexploited villages as part of regular activities in all districts from the year 2018-19 and so far, 35 such programmes are conducted benefitting $\sim 3500$ participants by the end of March 2020. As regulatory measures, the state is implementing TSWALTA-Act where powers are given to notify the over-exploited villages for control and regulation of groundwater development, registration of rigs etc.

\section{CONCLUSIONS AND WAY FORWARD}

\section{Conclusions}

- $\sim 85 \%$ of the state area is underlain by hard rock aquifers having poorer yields and rest by soft rock aquifers having good yields in north-eastern part of State.

- The State receives annual normal rainfall of $942 \mathrm{~mm}$ and is the main source of groundwater recharge.

- In the State, groundwater irrigation reached to its maximum of 23.35 lakh ha during 2017-18 from 0.46 lakh ha during 1875 and having well density of 13 wells $/ \mathrm{km}^{2}$ presently. About 57 percent of State population depends on agriculture and groundwater contributes 9.8 percent of State GDP.

- The average groundwater level in the State during last 35 years is showing decline in water level trends @ $0.18 \mathrm{~m} / \mathrm{yr}$ more particularly from areas that are lying in western parts of the State.

- Main issues identified in the State are water logging \& salinity in canal command areas of NSLC, SRSP \& Rajoli Bandha, overexploitation \& de-saturation of shallow aquifers in central and western part, groundwater pollution due to geogenic contamination by fluoride, anthropogenic contamination by nitrate and under-utilization of groundwater from highly potential sandstone aquifer in north-eastern parts.

- The management strategies adopted by Govt of Telangana like KLIS, Mission Kakatiya and Mission Bhagiratha are giving positive results in food production (this year total food grain production is expected at $13 \mathrm{MT}$ ) and in ameliorating groundwater conditions \& quality in affected areas.

\section{Way Forward}

No doubt the measures taken up by the Government of Telangana State are manifesting positive results. To sustain and to continue the impacts further, the following suggestions are made.

- Change in cropping pattern from highly water intensive crops like paddy in non-command areas to less water consuming irrigated dry (ID) crops and creating awareness through various IEC activities.

- The water logging and salinization is caused due to mis-management in irrigation system in general and can be solved through proper management of irrigation system by adopting conjunctive use of surface and groundwater and development of artificial drainage system as done earlier under water sector improvement project in NSLC command area from Khammam district.

- Implementing "warabandhi” (on/off) method of water releasing in water logged and prone to water logging areas in both kharif as well as rabbi seasons along with developing intercepting drains, soil treatment and declaring crop holidays.

- Improving water use efficiency in surface water supply through piped system at the delivery channel, micro-irrigation (drip \& sprinkler) and adopting other water conservation measures.

- Groundwater user associations at watershed/village level should be formed for making annual planning in cropping pattern based on rainfall and groundwater availability. 
- Monitoring mechanism existing in Groundwater Department of state and central should be strengthened and integrated by increasing scientific manpower, monitoring stations installed with automatic water level recorders. This will help in estimation of groundwater resources more precisely and accurately in future.

- As the electric pumps are extensively used for extraction of groundwater, controlling their use will go a long way in reducing extraction and this can be achieved by making separate grids for irrigation and other users on Gujarat model.

- For addressing drought and climate vulnerability, the participatory groundwater management must include policy interventions that involve regulatory mechanisms and villagebased institutions must be linked to government departments that manage groundwater (Reddy, V.R. and Reddy, M. S., 2020).

- Presently, the rights to groundwater belongs to the land owner and gets transferred and there is no control over its use, therefore land and water rights should be legally separated for better management as suggested by Gandhi and Bhamoriya (2011).

- Strict implementation of regulatory measures in controlling groundwater over-extraction in notified areas.

- In areas where underutilization of groundwater resources is there, more impetus to development of groundwater resources should be given under PMKSY (Har Khet ko Pani) scheme.

Acknowledgements: The authors thank Shri Somesh Kumar, IAS, the Chief Secretary to Govt. of Telangana and to Dr. Rajat Kumar, IAS, the Principal Secretary, (I \& CAD), for their constant encouragement and according permission to submit the paper. Thanks are due to Dr. S.K. Joshi, IAS, the Chief Secretary (retd.) who constantly encouraged the Department to contribute scientifically. The data collected and analysed by staff of SGWD Department is duly acknowledged. The views expressed by the authors are not necessarily that of Ground Water Department, Govt. of Telangana to which they belong.

\section{References}

BIS (Bureau of Indian Standards) (2012) Drinking water-specification IS 10500 $2^{\text {nd }}$ Revision (ICS 13.060.20), New Delhi, 16p.

CGWB (2010) Groundwater Exploration in Andhra Pradesh (as on March 2010). Government of India, Southern Region, Hyderabad, 207p.

CGWB (2019) National Compilation on Dynamic Ground Water Resources of India, Government of India, 298p.

DES (2017) Statistical Year Book, Department of Economic and Statistics, Government of Telangana, pp.135-144.

Dept. of Agriculture (2019) Agriculture Action Plan, Govt. of Telangana, 201924.

Dhawan, B.D. (1995) Groundwater Depletion, Land Degradation and Irrigated Agriculture in India, Commonwealth, Publishers, New Delhi.

FAO (2011) The State of the World's Land and Water Resources for Food and Agri-culture: Managing Systems at Risk. Earthscan, Abingdon, Oxfordshire, UK.

Foster, T., Brozovic, N. and Butler, A.P. (2015) Analysis of the impacts of well yield and groundwater depth on irrigated agriculture. Jour. Hydrol., v.523, pp. 86-89

Gandhi, V.P. and Bhamoriaya, V., (2011) Groundwater Irrigation in India Growth, Challenges and Risks. India Infrastructure Report, pp.90-117.

Giordano, M. (2009) Global Groundwater? Issues and Solutions. Annu. Rev. Environ. Resour. 34:7.1-7.26, 7.1-7.26.

Govt. of India (1972) Report of the irrigation Commission, Ministry of irrigation and Power, New Delhi, Vol-I. 430p.

Govt of India (2012) National Water Policy. Government of India, Ministry of Water Resources, Govt of India, New Delhi, 13p.

Govt. of India (2017) Report of $5^{\text {th }}$ census of Minor Irrigation Schemes, Government of India, Minor Irrigation (Statistics) Wing, 68p.

GSI (2018) Glimpses of GSI Activities in Telangana. State Unit Telangana, Geological Survey of India, Southern Region, Hyderabad, 34p.

Jeet, I (2005) Groundwater Resources of India: Occurrence, Utilization and Management, Mittal Publications, New Delhi.

Madhnure, P., Peddi, N.R. and Allani, D. R (2016) An integrated hydrogeo- logical study to support sustainable development and management of groundwater resources. A case study from the Pre-Cambrian Crystalline Province, India, Hydrogeol. Jour., v.24, pp.475-487.

Mahipal (1996) Million Wells Scheme: Loss or Gains, Economic and Political weekly. v.31(8), pp.447-449.

Moench, M. (2003) Groundwater and Food Security in India, in Kamta Prasad (ed.), Water Resources and Sustainable Development: Challenges of 21st Century, Shipra Publications, Delhi, pp.148-67.

NABARD (2020) State Focus Paper 2020-21, Telangana, National Bank for Agriculture and Rural Development, Telangana Regional Office, Hyderabad, 103p.

NABCONS Impact Assessment Study on Mission Kakatiya, Restoration of Minor Irrigation Tanks Implemented by Govt of Telangana, NABARD Consultancy Services Private Limited, 42p.

PD, Govt. of Telangana (2018) Socio Economic Outlook. Planning Department, Govt. of Telangana, $13 \mathrm{p}$.

PD, Govt. of Telangana (2020) Socio Economic Outlook. Planning Department, Govt. of Telangana, pp.21-42.

Pingale, G. (2011) Irrigation in Telangana: The rise and fall of tanks. Economic \& Political Weekly, June 2011. Vol XLVI Nos 26 \&27, pp.123-130.

Pradeepta Kumar Samantha (2015) A Study of Rural Electrification Infrastructure in India, Journal of Business and management (IOSR-JBM) Vol 17, Issue 2, ver-1 V, pp.54-59.

Puri, B.N. (1968) Irrigated agricultural economy in Ancient India, Annals of the Bhanderkar oriental research Institute, v.48/49, pp.383-390.

Ramachandra Guha (2017) India After Gandhi, The History of the World's Largest Democracy, Revised Ed, pp.198-207.

Reddy, V. Ratna; Reddy, M. Srinivasa. (2020). Can Participatory Groundwater Management Enhance Drought Resilience? The Case of the Andhra Pradesh Farmer-Managed Groundwater Systems Project. Water Knowledge Note; World Bank, Washington, DC. (C) World Bank. https:// open knowledge.worldbank.org/handle/10986/33243 License: CC BY 3.0 IGO.

Siebert, S., Burke, J., Faures, J.M., Frenken, K., Hoogeveen, J., Doll, P. and Portmann, F.T. (2010) Groundwater use for irrigation- a global inventory. Hydrol. Earth Syst. Sci., v.14, pp.1863-1880.

Saha, D., Marwah, S. \& Mukherjee, A (2018) Groundwater resources and sustainable management issues in India.In: Clean and Sustainable Groundwater in India. Springer. DOI:10.1007/978-981-104552-3_1.

Saha, D. and Ray, R (2018) Groundwater Resources in India. Potential, Challenges and Management-Issues and Challenges in South Asia, Springer. DOI:10.1007/978-3-319-75115-3-2.

SGWB \& CGWB (2019) Dynamic Groundwater Resources of Telangana (2016-17), State Ground Water Department, Government of Telangana and Central Ground Water Board, Government of India, 72p.

SGWD (2019a), Annual General Report (2018-19). State Ground Water Department, Government of Telangana, Hyderabad, 69p.

SGWD (2019b), Groundwater Quality in Principal Aquifers-2018, State Ground Water Department, Govt. of Telangana, Hyderabad, pp.28-31.

Shah, T. Molden, D., Sakthivadivel R., Seckler, D. (2000) The Global Groundwater Situation: Overview of Oppertunities and Challenges. Colombo, Sri Lanka: Int. Water Manag. Inst.

Shah, T.N., Burke, J., Villholth, K.G. and Giordano, M. (2007) Groundwater: a global assessment of scale and significance In Book: Water for food water for life: a Comprehensive Assessment of Water Management. In Agriculture, Chapter:10. Earthscan, London, UK, pp.395-423.

Sharad, K. Jain (2019) Water resource management in India-challenges and the way forward. Curr. Sci., v.117(4), pp.569-576.

Singh, D. (2003) 'Groundwater Markets and Institutional Mechanism in Fragile Environments'. In: Kanchan, Chopra, C.H. Hanumantha Rao, and Ramprasad, Sengupta (eds), Water Resources, Sustainable Livelihoods, and Eco-System Services, Concept Publishing Company, New Delhi, pp.311-40.

Sudarshan, G., Rao, P.N. and Rao, A.D. (2008) Change in groundwater scenario during the last five decades in Andhra Pradesh. Mem. Geol.Soc. India, No. 69, pp.21-38.

Suresh, A. and Manoj, P. Samuel (2020) Micro-irrigation development in India: challenges and strategies, Curr. Sci., v.118, No.8, 25 April 2020, pp.11631168.

World Bank (2019) Project Performance Assessment Report, India, Andhra Pradesh \& Telangana State Community-Based Tank Management Project (IBRD-48570, IDA-42910), 144222. 61p.

(Received: 8 May 2020; Revised form accepted: 25 September 2020) 